\title{
Legionnaires' disease in the time of COVID-19
}

\author{
Kelsie Cassell ${ }^{1 *}$, J Lucian Davis ${ }^{1,2}$ and Ruth Berkelman ${ }^{3}$
}

\begin{abstract}
Due to similarities in initial disease presentation, clinicians may be inclined to repeatedly test community-acquired pneumonia cases for COVID-19 before recognizing the need to test for Legionnaires' disease. Legionnaires' disease is an illness characterized by pneumonia that has a summer/early fall seasonality due to favorable conditions for Legionella growth and exposure. Legionella proliferate in warm water environments and stagnant sections of indoor plumbing and cooling systems. During the ongoing pandemic crisis, exposures to aerosolized water from recently reopened office or retail buildings should be considered as an epidemiologic risk factor for Legionella exposure and an indication to test. The majority of Legionnaires' disease cases occurring each year are not diagnosed, and some experts recommend that all patients hospitalized with community-acquired pneumonia without a known etiology be tested for Legionella infection. Proper diagnosis can increase the likelihood of appropriate and timely antibiotic treatment, identify potential clusters of disease, and facilitate source attribution.
\end{abstract}

Keywords: Legionnaires' disease, Epidemiology, COVID-19

As SARS-CoV-2 continues to sweep through the world's population, healthcare providers should be on heightened alert for another potential cause of pneumonia with similar symptoms: Legionnaires' disease. Public health professionals have recognized that due to the similarities in initial disease presentation, clinicians may repeatedly test for coronavirus disease 2019 (COVID-19) before recognizing the need to test for Legionnaires' disease. Legionnaires' disease is a common cause of communityacquired pneumonia with $~ 10 \%$ mortality; most patients require hospitalization with some progressing to acute respiratory failure leading to intensive care unit admission, similar to COVID-19 [1]. Infections are due to inhalation of aerosols containing Legionella. As buildings reopen and previously stagnant plumbing and cooling systems return to use, many additional cases could present to emergency departments in the coming months. Over the past two decades, U.S. incidence of Legionnaires' disease has increased over five-fold to

\footnotetext{
* Correspondence: kelsie.cassell@yale.edu

${ }^{1}$ Department of Epidemiology of Microbial Diseases, Yale School of Public Health, New Haven, CT, USA

Full list of author information is available at the end of the article
}

more than 3.0 cases per 100,000 population in 2018, with most cases occurring in the summer and early autumn (Fig. 1). Yet, Legionnaires' disease remains vastly underdiagnosed with the true number of cases estimated to be more than 50,000 per year [2].

Several reports have underscored the need for caution when re-opening buildings [3]. Aerosolization of waterborne Legionella can occur from both indoor and outdoor sources, including showers, gardening hoses, fountains, hot tubs, and cooling towers. Biofilms proliferate in water pipes under low-flow conditions, especially where disinfectant levels are inadequate or when building occupancy is low. Garrison et al. [4] noted that building-related Legionnaires' disease outbreaks investigated between 2000 and 2014 in North America included outbreaks attributed to low occupancy, closures of hospital wards, and water stagnation due to water flow disruptions (e.g. construction, water main break) [4]. As states relax lockdowns and physical distancing measures in response to COVID-19, the reopening of commercial buildings - and more importantly, the taps of their dormant plumbing systems - has the potential to expose large numbers of people to stagnant water containing Legionella spp. Additionally, these reopenings coincide

(c) The Author(s). 2021 Open Access This article is licensed under a Creative Commons Attribution 4.0 International License, which permits use, sharing, adaptation, distribution and reproduction in any medium or format, as long as you give appropriate credit to the original author(s) and the source, provide a link to the Creative Commons licence, and indicate if changes were made. The images or other third party material in this article are included in the article's Creative Commons licence, unless indicated otherwise in a credit line to the material. If material is not included in the article's Creative Commons licence and your intended use is not permitted by statutory regulation or exceeds the permitted use, you will need to obtain permission directly from the copyright holder. To view a copy of this licence, visit http://creativecommons.org/licenses/by/4.0/. 


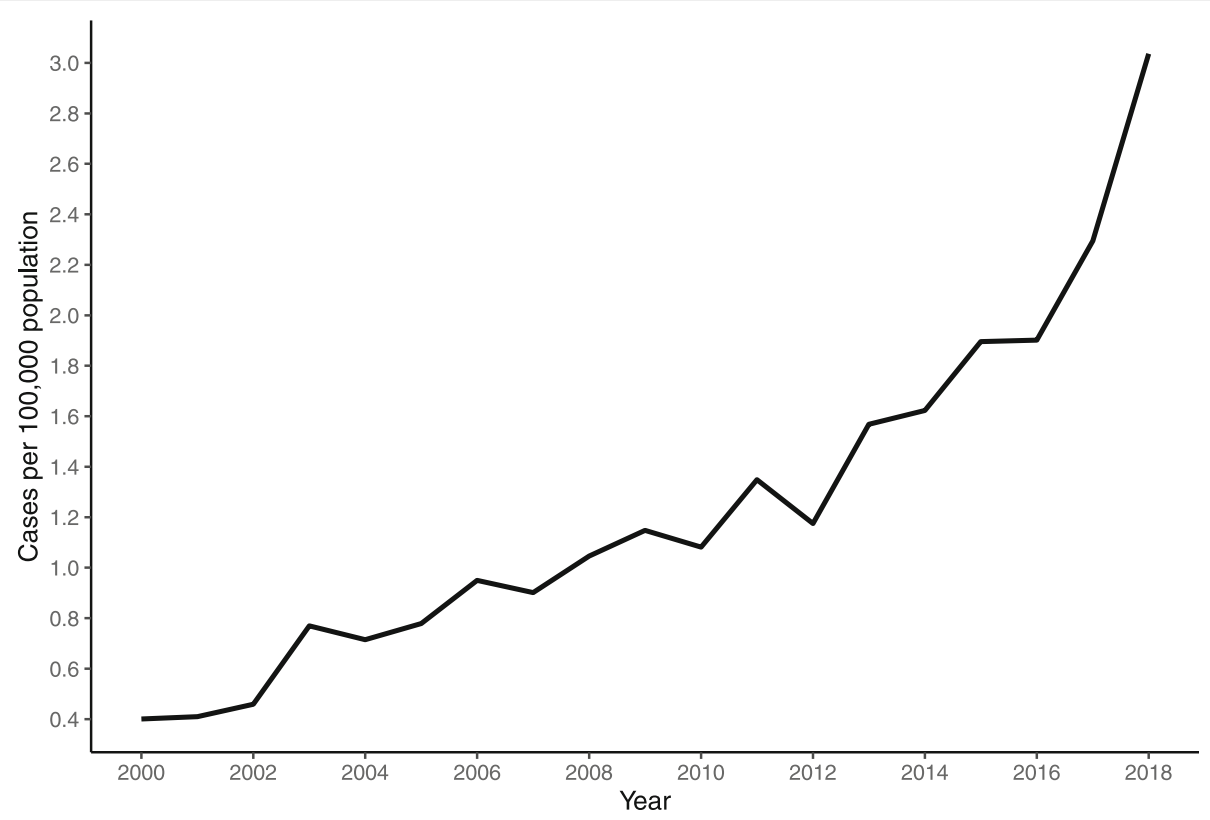

Fig. 1 Incidence of Legionnaires' disease in the United States, 2000 - 2018. Note: Data from the CDC National Notifiable Diseases Surveillance System, $2000-2018$

with the annual seasonal peak of Legionnaires' disease cases in the Northern hemisphere [5]. Over the last few months, the CDC, the EPA, and multiple professional societies (e.g. AIHA, ASHRAE) have issued guidance on safely reopening buildings in order to prevent Legionella growth and transmission linked to pandemic response measures $[3,6-8]$.

Pneumonia is the most common manifestation of both Legionnaires' disease and COVID-19, and initial presentation for both may include fever, headache, confusion, dyspnea, nausea, and diarrhea. Individual risk factors for both Legionnaires' disease and severe COVID-19 include older age, diabetes, and chronic lung disease. The incubation period for Legionnaires' disease is about 5 to 6 days but may range from 2 to 14 days, similar to COVID-19. Travel with overnight stays and healthcare exposure (e.g. hospitals, long-term care facilities) are known major risk factors for Legionnaires' disease [1]. During the ongoing pandemic crisis, exposures to aerosolized water from recently reopened office or retail buildings should also be considered as new risk factors for Legionella exposure. Additionally, changing behaviors in the home and for recreational activities during COVID-19 should be considered (e.g. gardening).

Because clinical manifestations may be indistinguishable between COVID-19 and Legionnaires' disease, targeted microbiologic testing for both Legionella and SARS-CoV2 are essential. The American Thoracic Society (ATS) and the Infectious Diseases Society of America (IDSA) guidelines for community-acquired pneumonia recommend Legionella urinary antigen testing (UAT) for severe disease in adults or those with epidemiological indications, in addition to sending sputum and other lower respiratory tract specimens for PCR and culture [9]. It is important to note that the UAT has a sensitivity around 70\% and a 99\% specificity but this is for Legionellapneumophila serogroup 1 and cannot reliably detect other pathogenic species and serogroups of Legionella that cause disease [10]. Historically, epidemiological indication referred to recent travel (e.g. hotels, cruises) or history of recent hospitalization or residence in a longterm care facility. Currently, it is important to consider other risk factors as well, including returning to work in reopened office buildings or patronizing businesses or other buildings that had been shuttered. The Centers for Disease Control and Prevention in Atlanta closed multiple buildings in August due to presence of Legionella in the buildings water systems, potentially linked to the long term building closure during the pandemic [11].

Some experts recommend that all patients hospitalized with pneumonia and without a known etiology be tested with UAT [2], however, IDSA/ITS guidelines recommend only severe CAP be tested with the UAT. This test is widely considered to have relatively low cost, with the ability to reduce discordant antibiotic therapy, and is of greater applicability in higher prevalence areas of the US $[12,13]$. Of note, coinfection with Legionella and SARS$\mathrm{CoV} 2$ has been documented [14]. Because the UAT cannot detect Legionella caused by non-Legionella pneumophila serogroup 1 , and because morbidity and mortality due to 
Legionella are high, ATS/IDSA guidelines also recommend early empiric antimicrobial therapy with a fluoroquinolone or macrolide such as azithromycin and levofloxacin [1].

Because empiric treatment of Legionnaires' disease is not always effective, early testing including UAT could improve the clinical and public health response. Like COVID-19, public health officials require a laboratory diagnosis to investigate cases, which could lead to identification of the exposure source. Such actions will reduce morbidity and mortality from this severe and increasingly common disease.

\begin{abstract}
Abbreviations
COVID-19: Coronavirus disease 2019; CDC: Centers for Disease Control and Prevention; EPA: Environmental Protection Agency; AlHA: American Industrial Hygiene Association; ASHRAE: American Society of Heating, Refrigerating, and Air Conditioning Engineers; UAT: Legionella urinary antigen testing; ATS/ IDSA: The American Thoracic Society (ATS)/The Infectious Diseases Society of America
\end{abstract}

\section{Acknowledgements}

The authors would like to acknowledge the CDC Legionella Epidemiology Team, including, but not limited to, Jessica Smith, MPH, Elizabeth Hannapel, $\mathrm{MPH}$, and Chris Edens, PhD.

\section{Authors' contributions}

$K C, J L D$, and $R B$ all contributed equally to the design and drafting of this manuscript. The author(s) read and approved the final manuscript.

\section{Funding}

Not applicable.

\section{Availability of data and materials}

The datasets used to generate Fig. 1 are available from CDC National Notifiable Diseases Surveillance System, 2000-2018.

\section{Ethics approval and consent to participate}

Not applicable

\section{Consent for publication}

Not applicable

\section{Competing interests}

The authors declare that they have no competing interests

\section{Author details}

${ }^{1}$ Department of Epidemiology of Microbial Diseases, Yale School of Public Health, New Haven, CT, USA. ${ }^{2}$ Pulmonary, Critical Care, and Sleep Medicine Section, Yale School of Medicine, New Haven, CT, USA. ${ }^{3}$ Rollins School of Public Health, Emory University, Atlanta, GA, USA.

Received: 7 August 2020 Accepted: 20 December 2020

Published online: 06 January 2021

\section{References}

1. Phin N, Parry-Ford F, Harrison T, Stagg HR, Zhang N, Kumar K, et al. Epidemiology and clinical management of Legionnaires' disease. Lancet Infect Dis. 2014;14(10):1011-21. Available from: https://www.sciencedirect. com/science/article/pii/S1473309914707133

2. National Academies of Sciences Engineering and Medicine. Management of Legionella in Water Systems. Management of Legionella in Water Systems. Washington, DC: National Academies Press; 2019.

3. Proctor CR, Rhoads WJ, Keane T, Salehi M, Hamilton K, Pieper J, et al. Considerations for Large Building Water Quality after Extended Stagnation Potential Keywords. OSF Prepr. 2020.

4. Garrison LE, Kunz JM, Cooley LA, Moore MR, Lucas C, Schrag S, et al. Vital Signs: Deficiencies in Environmental Control Identified in Outbreaks of Legionnaires' Disease-North America, 2000-2014. Am J Transplant. 2016;
16(10):3049-58. Available from: https://doi.org/http://doi.wiley.com/10.1111/ ajt.14024. [cited 2020 Jun 4].

5. Simmering JE, Polgreen LA, Hornick DB, Sewell DK, Polgreen PM. WeatherDependent Risk for Legionnaires' Disease, United States. Emerg Infect Dis [Internet]. 2017;23(11). Available from: http://wwwnc.cdc.gov/eid/ article/23/11/17-0137_article.htm. [cited 2017 Oct 11].

6. Guidance for Reopening Buildings After Prolonged Shutdown or Reduced Operation. | CDC. Available from: https://www.cdc.gov/coronavirus/2019ncov/php/building-water-system.html. [cited 2020 Jun 5].

7. EPA. Maintaining or Restoring Water Quality in Buildings with Low or No Use.

8. AlHA. Recovering. from COVID-19 Building Closures Guidance. Available from: https://www.epa.gov/pesticide-registration/list-n-disinfectants-useagainst-sars-cov-2. [cited 2020 Jun 5].

9. Metlay JP, Waterer GW, Long AC, Anzueto A, Brozek J, Crothers K, et al. Diagnosis and Treatment of Adults with Community-acquired Pneumonia. Am J Respir Crit Care Med. 2019;200(7):45-67. Available from: http://www. atsjournals.org/doi/supplhttps://doi.org/10.1164/rccm.201908-1581ST. [cited 2020 Jun 5].

10. Shimada T, Noguchi Y, Jackson JL, Miyashita J, Hayashino Y, Kamiya T, et al. Systematic Review and Metaanalysis: Urine Antigen Tests for Legionellosis. Chest. 2009;136(6):1576-85. Available from: http://linkinghub.elsevier.com/ retrieve/pii/S001236920960739X. [cited 2016 Oct 20].

11. C.D.C. Closes Some Offices Over Bacteria Discovery - The New York Times. Available from: https://www.nytimes.com/2020/08/08/health/cdclegionnaires-coronavirus.html. [cited 2020 Dec 14].

12. Reller L, Weinstein MP, Murdoch DR. Diagnosis of Legionella Infection. Clin Infect Dis. 2003;36(1):64-9. Available from: https://academic.oup.com/cid/ article-lookup/doi/10.1086/345529. [cited 2019 Apr 29].

13. Henry C, Boethel C, Copeland LA, Ghamande S, Arroliga AC, White HD. Clinical Utility of Testing for Legionella Pneumonia in Central Texas. Ann Am Thorac Soc. 2017;14(1):65-9. Available from: http://www.atsjournals.org/doi/ https://doi.org/10.1513/AnnalsATS.201606-501BC. [cited 2019 Nov 16].

14. Arashiro T, Nakamura S, Asami T, Mikuni H, Fujiwara E, Sakamoto S, et al. SARS-COV-2 and Legionella co-infection in a person returning from a Nile cruise. J Travel Med. 2020;2020:1-3. Available from: https:/academic.oup. com/jtm/article-abstract/27/3/taaa053/5820898. [cited 2020 May 22].

\section{Publisher's Note}

Springer Nature remains neutral with regard to jurisdictional claims in published maps and institutional affiliations.

\section{Ready to submit your research? Choose BMC and benefit from:}

- fast, convenient online submission

- thorough peer review by experienced researchers in your field

- rapid publication on acceptance

- support for research data, including large and complex data types

- gold Open Access which fosters wider collaboration and increased citations

- maximum visibility for your research: over $100 \mathrm{M}$ website views per year

At BMC, research is always in progress.

Learn more biomedcentral.com/submissions 